\title{
27. VARIATION IN SINGLE COOLING UNITS AT HOLE 418A, DEEP SEA DRILLING PROJECT: EFFECTS OF ALTERATION AND PHENOCRYST REDISTRIBUTION
}

\author{
M. F. J. Flower, ${ }^{1}$ Smithsonian Institution, Museum of Natural History, Washington, D.C. \\ R. G. Pritchard, Department of Geology, University of Newcastle-upon-Tyne, NE1 7RU, England \\ and \\ H. Puchelt, Petrographisches Institut der Universität, D-7500, Karlsruhe 1, West Germany
}

\section{INTRODUCTION}

To assist in the interpretation of altered and fresh lava chemistry at Sites 417 and 418 , we sampled and analyzed in some detail single cooling units from Hole 418A during Leg 53. Similar studies from previous Legs (e.g., Baragar et al., 1977) had been concerned with alteration phenomena in comparatively young crust (less than $13 \mathrm{~m} . \mathrm{y}$. old) at the Mid-Atlantic Ridge (MAR). Mineralogic and chemical information from basalts at Sites 417 and 418 (this volume) indicate the pattern of alteration differs only slightly from that in the newer crust. A complicating factor is the movement of phenocrysts during and after eruption which may cause substantial variation of $\mathrm{MgO}, \mathrm{FeO}, \mathrm{CaO}$, and $\mathrm{SiO}_{2}$ contents, all of which could be subject to mobilization through alteration. Post-eruptive phenocryst-liquid differentiation appears to be highly characteristic of submarine, as opposed to subaerially, erupted lavas. In this study, we have attempted to model this effect by least-squares analysis of sample compositions and to calculate the residual mass transfer caused by low-temperature alteration.

Up to 10 samples were taken from single pillows or identifiable flow units in order to represent: (a) fresh interiors of pillows and massive units, (b) incipient alteration fronts, and (c) intense alteration reactions at cooling unit margins, where primary mineral and glass assemblages are largely replaced. Wherever possible, we have estimated the extent of intra-unit phenocryst redistribution according to the hypothetical mixing relationship:

$$
P=a \pm b \pm c \pm d \text {. }
$$

Here $P$ is a "parent" and $D$ a "daughter" composition, and $a, b$, and $c$ are mineral-phase compositions. We derived least-squares solutions for the equations by substituting plagioclase, olivine, and clinopyroxene phenocryst compositions, An75-85, Fo75-85, and EnsoFs7 W043, respectively, for appropriate whole-rock composition pairs. "Immobile" oxides such as $\mathrm{TiO}_{2}, \mathrm{P}_{2} \mathrm{O}_{5}$, and $\mathrm{Al}_{2} \mathrm{O}_{3}$ were weighed high in the least-squares calculations (Pearce et al., 1977; Pearce and Cann, 1971). As variation between $P$ and $D$ is assumed to be determined simply by phenocryst fractionation and alteration, oxide residuals from the least-squares solutions are taken to indicate element mobility during alteration processes. The validity of the mass balance models is assessed in terms of the primary and secondary mineralogy and phase

${ }^{1}$ Present address: 25 Willes Road, London NW5, England. chemistry (Robinson et al., this volume; Pritchard, this volume).

Flower et al. (this volume) have divided the drilled core into "structural"' or lithologic "sub-" units. In addition to breccia and sediment intercalations, these comprise individual cooling units identified by an examination of actual and photographed core samples. We have used the sub-unit divisions as a reference for all cooling units studied.

\section{INSTRUMENTATION}

Analysis for $\mathrm{Si}, \mathrm{Ti}, \mathrm{Al}, \mathrm{Fe}, \mathrm{Mg}, \mathrm{Ca}, \mathrm{K}$, and $\mathrm{P}$ was carried out on ignited samples onboard Glomar Challenger by means of the C.N.E.X.O. Siemens XRF van, using calibration curves established for reference standards BR, BCR 1 , AGV 1, DTS 1, PCC 1, and MAR. Carbon dioxide and $\mathrm{H}_{2} \mathrm{O}^{+}$were analyzed by means of a $\mathrm{CHN}$ analyzer on board. $\mathrm{Na}$ and $\mathrm{Mn}$ were analyzed at the Petrographisches Institut, Karlsruhe, by Instrumental Neutron Activation Analysis, using a BCR reference standard.

\section{MAJOR OXIDE VARIATION}

Each analysis has been reduced to a water-free basis, corrected for carbonate addition by subtraction of a $\mathrm{CO}_{2}$ equivalent amount of $\mathrm{CaO}$ and normalized to 100 wt. per cent. Carbonate correction is required by the presence of stoichiometric $\mathrm{CaCO}_{3}$ as a vein and vug filling, and appears to reduce $\mathrm{CaO}$ to "uncontaminated" magmatic values. Computer file numbers, their corresponding DSDP sample reference numbers and sub-unit numbers, and $\mathrm{H}_{2} \mathrm{O}^{+}$and $\mathrm{CO}_{2}$ values are given in Table 1; carbonate-corrected normalized analyses are given in Table 2 . Variation of major oxides versus $\mathrm{MgO}$ is shown for 12 single units in Figures 1 through 10 . These units were selected to represent the predominant variation types in the Hole 418A basalts. Empirically, we find that incipient growth of secondary phases (e.g., in the groundmass) is not characterized by significant major oxide mobility; so we refer to this material as " fresh," as far as its (dry-weight) chemistry is concerned. We use the term "altered" to denote a sample whose primary mineralogy is largely converted to secondary phases. The petrography and chemistry of units studied will now be considered:

\section{Sub-Unit 398: Sample 57-1, $41 \mathrm{~cm}$ to Sample 57-2, $20 \mathrm{~cm}$, a 1.3-Meter-Thick Pillow in Lithologic Unit 8}

This pillow is moderately phyric (plagioclase $>$ olivine $>$ clinopyroxene), with an upper glass cooling rind converted to green and brown smectite. Analyses 1550 (A), 1560 (B), 
TABLE 1

Leg 53 Samples Used in Single Cooling-Unit Studies at Hole 418A

\begin{tabular}{|c|c|c|c|c|c|}
\hline $\begin{array}{c}\text { Computer } \\
\text { File No. }\end{array}$ & Sub-Unit & $\begin{array}{c}\text { Sample } \\
\text { (Interval in } \mathrm{cm} \text { ) }\end{array}$ & $\begin{array}{c}\text { Depth Below } \\
\text { Sea Floor } \\
\text { (m) }\end{array}$ & $\begin{array}{l}\mathrm{H}_{2} \mathrm{O}^{+} \\
\text {(wt. } \% \text { ) }\end{array}$ & $\underset{\text { (wt. \%) }}{\mathrm{CO}_{2}}$ \\
\hline 1550 & 398 & $57-1,50-54$ & 639.5 & 0.88 & 0.60 \\
\hline 1560 & - & $57-1,67-68$ & 639.5 & 0.79 & 0.15 \\
\hline 1570 & - & $57-1,90-92$ & 640 & 0.85 & 0.36 \\
\hline 1660 & 442 & $60-4,121-124$ & 673 & 1.18 & 0.83 \\
\hline 1670 & - & $60-5,25-27$ & 675 & 1.39 & 0.86 \\
\hline 1930 & 542 & $70-4,26-29$ & 749 & 0.45 & 1.73 \\
\hline 1940 & 543 & $70-4,96-99$ & 749.5 & 1.32 & 0.48 \\
\hline 1950 & - & $70-4,134-138$ & 749.5 & 0.58 & 1.93 \\
\hline 1960 & 544 & $70-5,68-71$ & 750 & 0.35 & 2.14 \\
\hline 2000 & 568 & $72-4,98-99$ & 764 & 0.80 & 1.09 \\
\hline 2010 & - & $72-4,99-102$ & 764 & 0.43 & 0.94 \\
\hline 2020 & 569 & $73-1,65-66$ & 765.5 & 1.90 & 0.25 \\
\hline 2030 & - & $73-1,66-68$ & 765.5 & 0.69 & 0.39 \\
\hline 2040 & - & $73-1,105-107$ & 766 & 0.60 & 0.35 \\
\hline 2050 & - & $73-1,130-137$ & 766 & 2.40 & 0.29 \\
\hline 2060 & - & $73-1,130-137$ & 766 & 0.50 & 1.33 \\
\hline 2120 & 592 & $74-6,85-86$ & 780 & 1.69 & 0.18 \\
\hline 2130 & - & $74-6,86-88$ & 780 & 5.72 & 0.21 \\
\hline 2160 & 601 & $75-4,23-24$ & 785 & 3.45 & 0.27 \\
\hline 2170 & - & $75-4,24-25$ & 785 & 0.92 & 0.22 \\
\hline 2180 & 607 & $76-1,115-118$ & 790.5 & 0.92 & 0.84 \\
\hline 2190 & - & $76-3,125-130$ & 792.5 & 1.16 & 1.69 \\
\hline 2210 & 611 & $77-5,84-86$ & 799 & 0.50 & 0.78 \\
\hline 2220 & - & $77-7,11-13$ & 801.5 & 0.73 & 1.24 \\
\hline 2230 & - & $78-2,35-37$ & 804 & 0.42 & 1.00 \\
\hline 2240 & - & $78-2,140-142$ & 805 & 0.48 & 0.92 \\
\hline 2250 & - & $78-4,0-3$ & 806.5 & 0.50 & 0.68 \\
\hline 2260 & - & $78-7,57-59$ & 811 & 0.56 & 0.78 \\
\hline 2340 & 624 & $80-7,0-2$ & 829.5 & 0.39 & 0.49 \\
\hline 2350 & - & $81-2,19-21$ & 833 & 0.43 & 0.54 \\
\hline 2360 & - & $81-5,133-135$ & 836.5 & 0.44 & 0.29 \\
\hline 2390 & - & $82-2,130-133$ & 839.5 & 0.49 & 0.23 \\
\hline 2400 & - & $83-1,71-75$ & 841 & 0.66 & 0.50 \\
\hline 2410 & - & $83-4,8-12$ & 844.5 & 4.56 & 0.92 \\
\hline 2420 & - & $84-4,48-51$ & 849 & 0.74 & 0.28 \\
\hline 2430 & - & $85-2,42-44$ & 852 & 0.96 & 0.39 \\
\hline 2440 & - & $85-6,77-79$ & 857 & 0.54 & 0.98 \\
\hline 2450 & - & $86-1,14-19$ & 860 & 0.57 & 0.44 \\
\hline
\end{tabular}

and $1570(\mathrm{C})$ (Figure 1) span $50 \mathrm{~cm}$ from the upper margin into the pillow. A typical pattern shows increased alteration at the margin (A), which is overlain by a chert intercalation. $\mathrm{B}$ and $\mathrm{C}$ (Figure 1) are fresh and show little chemical or lithologic differences. Compared to fresh glass from this unit (G) (microprobe analysis data from Byerly and Sinton, this volume), $\mathrm{B}$ and $\mathrm{C}$ have accumulated 8 to 10 per cent plagioclase, 5 per cent olivine, and $<1$ per cent clinopyroxene. Additional plagioclase accumulation is reflected by A (about 2\%), which otherwise shows the effects of leaching of $\mathrm{Ca}^{+2}$ and $\mathrm{Mg}^{+2}$, and addition of $\mathrm{K}^{+}$and $\mathrm{Si}^{+4}$ (Figure 1).

\section{Sub-Unit 442: Sample 60-4, $33 \mathrm{~cm}$ to Sample 60-6, $65 \mathrm{~cm}$, a Highly Vesicular Massive Flow Comprising Lithologic Unit 9}

Plagioclase (5 to 10 modal per cent) is the only phenocryst phase in this unit. Vesicles are filled mostly with carbonate and green and/or brown smectite, and increase upwards to the brecciated top. Analyses 1660 (A), about 85 $\mathrm{cm}$ from the upper margin and 1670 (B), about $50 \mathrm{~cm}$ below A (Figure 2), indicate incipient alteration of A with development of brown smectite. B is fresh, although it has a higher $\mathrm{H}_{2} \mathrm{O}^{+}$content than $\mathrm{A}$ (Table 1) and a slightly higher proportion of plagioclase phenocrysts, both effects are superimposed. Extraction of 5 per cent plagioclase from A would produce $\mathrm{TiO}_{2}$ and $\mathrm{Al}_{2} \mathrm{O}_{3}$ contents similar to those from B, with residuals implying leaching of small amounts of $\mathrm{Ca}^{+2}$ and $\mathrm{Mg}^{+2}$ and enrichment of $\mathrm{K}^{+}$and $\mathrm{Si}^{+4}$.

Sub-Unit 568: Sample 72-4, $97 \mathrm{~cm}$ to Sample 73-1, $65 \mathrm{~cm}$, a 1-Meter-Thick Pillow in Lithologic Unit 13, Moderately Phyric With 10 Per Cent Plagioclase, 5 Per Cent Olivine, and 2 Per Cent Clinopyroxene Phenocrysts

Vesicles are sparse and filled with smectite and calcite. Incipient alteration of groundmass has produced green smectite, but glass chill rinds are partly fresh, with brown smectite and calcite veining at the very edge. Samples 2000 (A), the altered upper glassy margin, and 2010 (B), a fresh zone 1 to $2 \mathrm{~cm}$ below A, show small phenocrysts or pseudomorphs of plagioclase, olivine, and possibly clinopyroxene, in similar modal proportions. Compared to B, A

TABLE 2

Leg 53 Shipboard Analyses Used in Single Cooling-Unit Studies at Hole 418A, Corrected for Carbonate (see text) and Normalized to Dry Weight Assuming All Iron Oxide to be $\mathrm{FeO}^{\mathrm{a}}$

\begin{tabular}{|c|c|c|c|c|c|c|c|c|c|c|c|c|c|c|c|c|c|c|c|c|}
\hline & 1550 & 1560 & 1570 & 1930 & 1940 & 1950 & 1960 & 2000 & 2010 & 2020 & 2030 & 2040 & 2050 & 2060 & 2120 & 2130 & 2160 & 2170 & 2180 & 2190 \\
\hline $\mathrm{SiO}_{2}$ & 51.10 & 49.94 & 50.25 & 50.61 & 50,83 & 50.60 & 50.08 & 51.01 & 50.15 & 52.65 & 50.89 & 50.31 & 49.16 & 52.62 & 50.89 & 48.89 & 50.39 & 49.54 & 50.15 & 50.13 \\
\hline $\mathrm{Al}_{2} \mathrm{O}_{3}$ & 16.79 & 16.23 & 15.84 & 15.33 & 15.72 & 15.53 & 15.87 & 15.99 & 15.57 & 16.05 & 15.78 & 15.90 & 15,01 & 15.85 & 17.09 & 16.90 & 15.59 & 16.12 & 16.60 & 16.74 \\
\hline FeO* & 10.03 & 10.41 & 10.62 & 9.69 & 10.96 & 10.26 & 9.93 & 9.14 & 9.59 & 10.20 & 9.89 & 9.97 & 9.95 & 10.91 & 11.90 & 11.39 & 11.62 & 9.78 & 9.84 & 9.79 \\
\hline $\mathrm{MgO}$ & 5.60 & 6.01 & 6.17 & 7.78 & 7.51 & 7.92 & 7.03 & 7.43 & 8.12 & 6.71 & 8.13 & 7.27 & 7.31 & 7.28 & 6.73 & 7.56 & 8.45 & 7.92 & 7.11 & 7.00 \\
\hline $\mathrm{CaO}$ & 12.00 & 13.28 & 12.72 & 12,32 & 11.05 & 11.72 & 13.00 & 12.19 & 12.71 & 9.65 & 11.45 & 12.54 & 14.23 & 8.43 & 8.64 & 11.32 & 9.26 & 12.47 & 12.18 & 11.65 \\
\hline $\mathrm{Na}_{2} \mathrm{O}$ & 2.43 & 2.30 & 2.33 & 2.35 & 2.28 & 2.25 & 2.36 & 2.35 & 2.19 & 1.98 & 2.13 & 2.30 & 2.62 & 2.33 & 1.95 & 2.03 & 2.21 & 2.38 & 2.42 & 2.77 \\
\hline $\mathrm{K}_{2} \mathrm{O}$ & 0.15 & 0.04 & 0.09 & 0.11 & 0.09 & 0.06 & 0.08 & 0.36 & 0.08 & 1.28 & 0.15 & 0.11 & 0.12 & 0.93 & 1.19 & 0.41 & 0.86 & 0.09 & 0.05 & 0.08 \\
\hline $\mathrm{TiO}_{2}$ & 1.52 & 1.43 & 1.52 & 1.47 & 1.27 & 1.35 & 1.30 & 1.24 & 1.29 & 1.26 & 1.30 & 1.32 & 1.29 & 1.34 & 1.35 & 1.32 & 1.34 & 1.35 & 1.37 & 1.52 \\
\hline $\mathrm{P}_{2} \mathrm{O}_{5}$ & 0.22 & 0.17 & 0.28 & 0.14 & 0.12 & 0.12 & 0.13 & 0.13 & 0.12 & 0.10 & 0.12 & 0.10 & 0.15 & 0.08 & 0.12 & 0.10 & 0.14 & 0.12 & 0.10 & 0.14 \\
\hline MnO & 0.15 & 0.17 & 0.17 & 0.19 & 0.16 & 0.18 & 0.21 & 0.15 & 0.17 & 0.11 & 0.15 & 0.17 & 0.14 & 0.22 & 0.13 & 0.07 & 0.13 & 0.21 & 0.17 & 0.18 \\
\hline \multirow[t]{2}{*}{ Total } & 100.00 & 100.00 & 100.00 & 100.00 & 100.00 & 100.00 & 100.00 & 100.00 & 100.00 & 100.00 & 100.00 & 100.00 & 100.00 & 100.00 & 100.00 & 100.00 & 100.00 & 100.00 & 100.00 & 100.00 \\
\hline & 2210 & 2220 & 2230 & 2240 & 2250 & 2260 & 2340 & 2350 & 2360 & 2390 & 2400 & 2410 & 2420 & 2430 & 2440 & 2450 & & & & \\
\hline $\mathrm{SiO}_{2}$ & 50.36 & 50.73 & 50.93 & 51.02 & 51.07 & 51.37 & 50.28 & 50.45 & 50.39 & 50.26 & 49.84 & 51.34 & 49.08 & 50.21 & 50.31 & 49.64 & & & & \\
\hline $\mathrm{Al}_{2} \mathrm{O}_{3}$ & 16.74 & 16.04 & 15.60 & 15.36 & 15.64 & 15.51 & 16.59 & 16.10 & 15.16 & 15.97 & 16.27 & 15.99 & 16.15 & 15.55 & 15.97 & 15.58 & & & & \\
\hline $\mathrm{FeO}$ & 9.81 & 9.33 & 9.68 & 9.88 & 9.92 & 9.74 & 10.12 & 9.93 & 10.48 & 9.96 & 10.15 & 8.49 & 9.96 & 9.92 & 9.68 & 9.79 & & & & \\
\hline $\mathrm{MgO}$ & 6.19 & 6.71 & 6.74 & 6.54 & 6.62 & 6.87 & 6.19 & 6.70 & 7.47 & 7.37 & 7.07 & 9.65 & 8.98 & $8.0 ?$ & 8.27 & 8.53 & & & & \\
\hline $\mathrm{CaO}$ & 13.03 & 13.18 & 13.13 & 13.21 & 12.79 & 12.55 & 12.86 & 12.75 & 12.34 & 12.60 & 12.86 & 7.44 & 12.38 & 12.52 & 11.93 & 12.36 & & & & \\
\hline $\mathrm{Na}_{2} \mathrm{O}$ & 2.27 & 2.32 & 2.25 & 2.26 & 2.29 & 2.27 & 2.26 & 2.39 & 2.39 & 2.25 & 2.31 & 4.40 & 2.00 & 2.18 & 2.22 & 2.34 & & & & \\
\hline $\mathrm{K}_{2} \mathrm{O}$ & 0.03 & 0.06 & 0.06 & 0.06 & 0.03 & 0.03 & 0.03 & 0.03 & 0.03 & 0.03 & 0.03 & 1.46 & 0.03 & 0.03 & 0.03 & 0.11 & & & & \\
\hline $\mathrm{TiO}_{2}$ & 1.25 & 1.33 & 1.30 & 1.33 & 1.31 & 1.34 & 1.36 & 1.35 & 1.41 & 1.29 & 1.20 & 1.02 & 1.16 & 1.22 & 1.28 & 1.30 & & & & \\
\hline $\mathrm{P}_{2} \mathrm{O}_{5}$ & 0.13 & 0.14 & 0.14 & 0.15 & 0.15 & 0.12 & 0.14 & 0.13 & 0.13 & 0.10 & 0.12 & 0.12 & 0.09 & 0.12 & 0.14 & 0.11 & & & & \\
\hline $\mathrm{MnO}$ & 0.18 & 0.15 & 0.16 & 0.18 & 0.17 & 0.19 & 0.17 & 0.17 & 0.19 & 0.17 & 0.15 & 0.08 & 0.16 & 0.17 & 0.16 & 0.22 & & & & \\
\hline Total & 100.00 & 100.00 & 100.00 & 100.00 & 100.00 & 100.00 & 100.00 & 100.00 & 100.00 & 100.00 & 100.00 & 100.00 & 100.00 & 100.00 & 100.00 & 100.00 & & & & \\
\hline
\end{tabular}

analysts: R.G. Pritchard and H. Puchelt. 

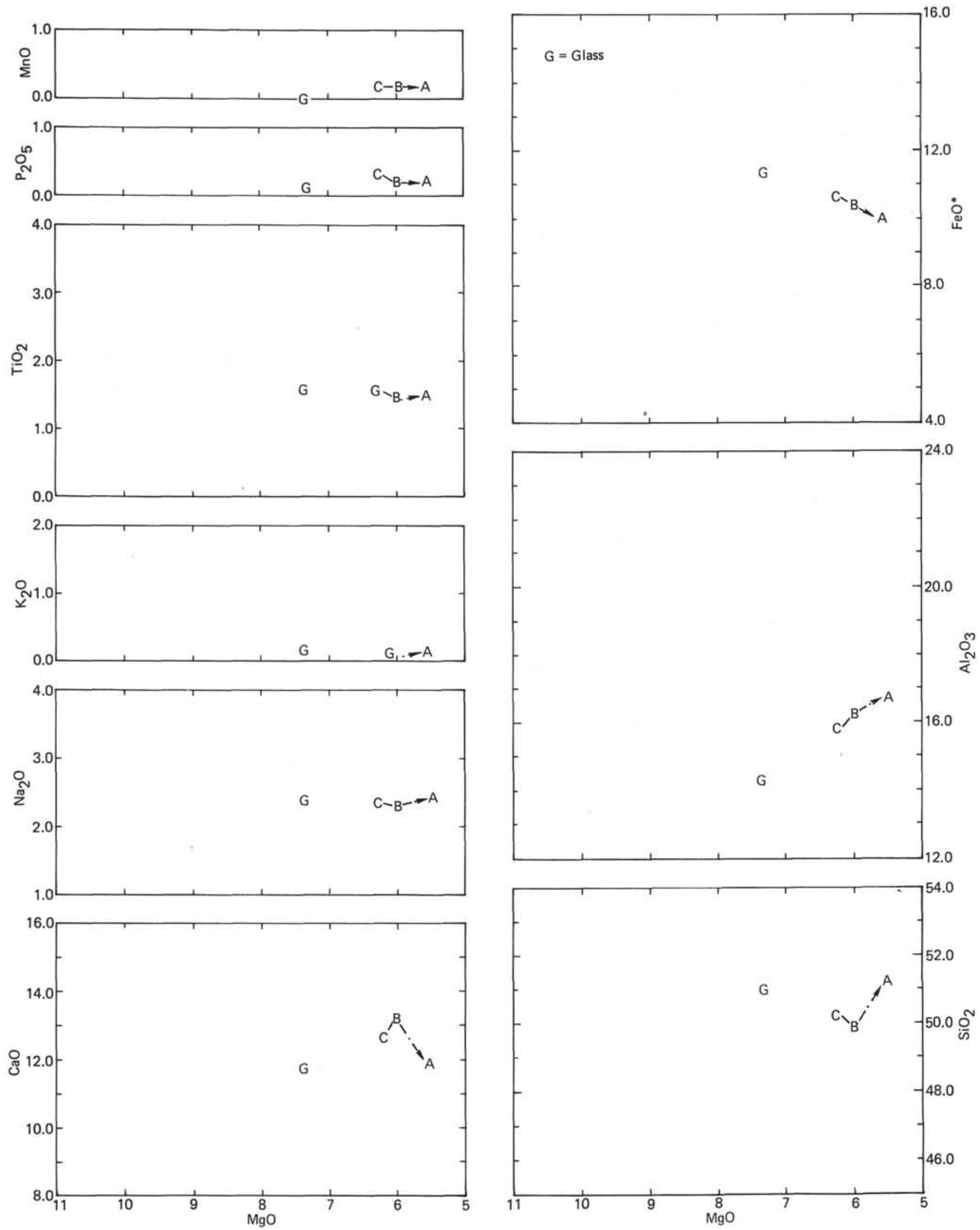

Figure 1. Plots of major and minor oxides versus $\mathrm{MgO}$ for single cooling units; Deep Sea Drilling Project Leg 53 shipboard analyses with $\mathrm{CaO}$ values corrected for carbonate contamination, normalized to dry-weight basis, with total iron oxide expressed as FeO. Dashed arrows: Variation due to low-temperature alteration. Dot-dash arrows: Variation due to both alteration and phenocryst redistribution. Hole 418A, single cooling unit, lithologic Sub-unit 398 , Core 57. 


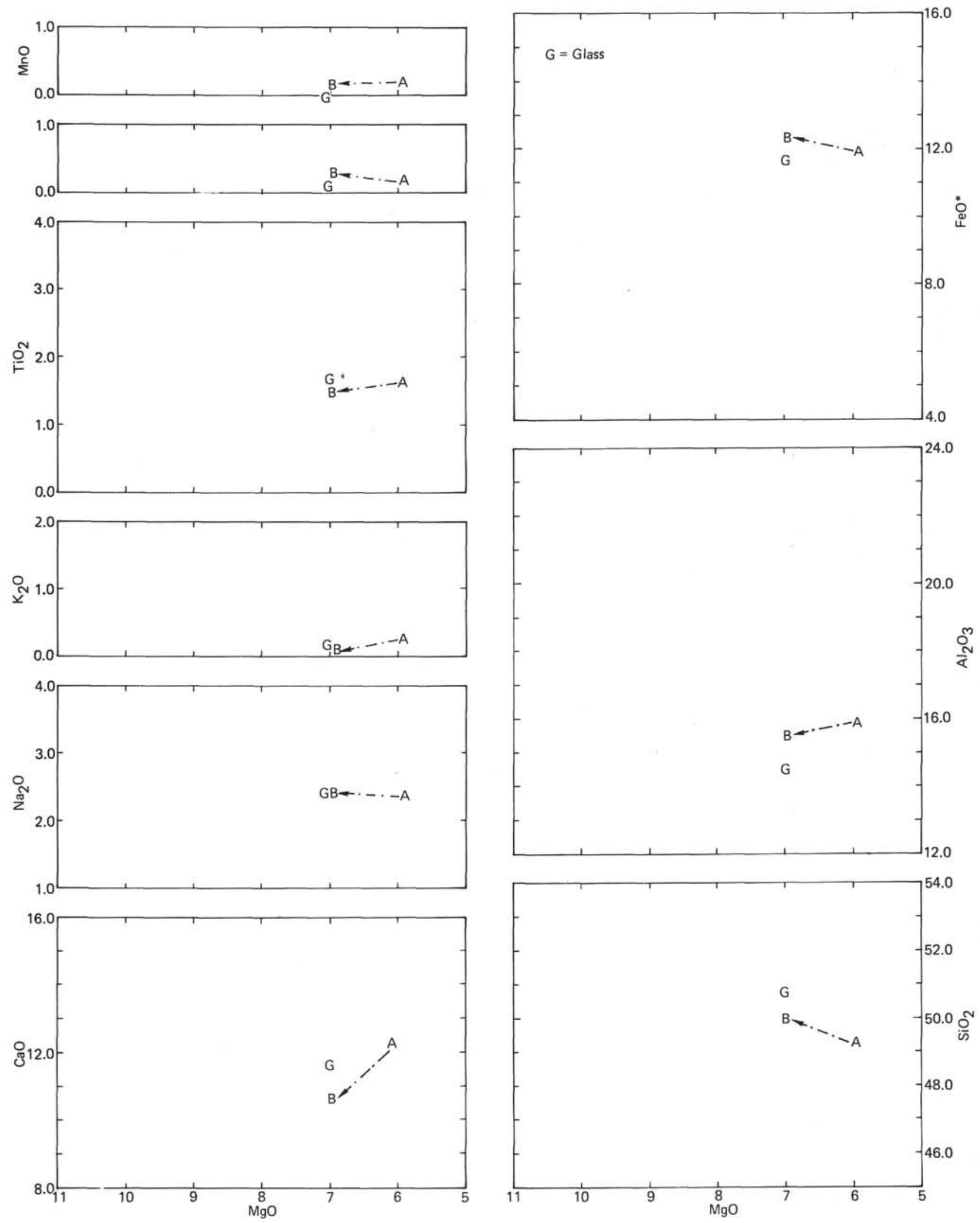

Figure 2. Hole 418A, single cooling unit, lithologic Sub-unit 442, Core 60. Legend as in Figure 1. 
shows leaching of $\mathrm{Ca}^{+2}$ and $\mathrm{Mg}^{+2}$, but not $\mathrm{Na}^{+}$, together with strong enrichment of $\mathrm{Si}^{+4}$ and $\mathrm{K}$ (Figure 3). Compared to a microprobe analysis of fresh glass from the same rind (Byerly and Sinton, this volume), least-squares computation indicates that $\mathrm{B}$ has accumulated 12 per cent plagioclase, 8.1 per cent olivine, and 2.8 per cent clinopyroxene.

Sub-Unit 569: Sample 73-1, $65 \mathrm{~cm}$ to Sample 73-1, $130 \mathrm{~cm}$, a 65-cm-Thick Pillow in Lithologic Unit 13, Moderately Phyric, With 10 Per Cent Plagioclase, 5 Per Cent Olivine, and 5 Per Cent Clinopyroxene Phenocrysts, and Groundmass Showing Incipient Alteration

Upper and lower cooling rinds were analyzed across oxidative(?) (yellow-brown) alteration gradients, with one representative of the fresh pillow interior. Analyses 2020 (A, altered) and 2030 (B, fresh, 1 to $2 \mathrm{~cm}$ below A) are of the upper margin, 2040 (C) of the fresh pillow center, and 2050 (D, ? fresh, but with high $\mathrm{H}_{2} \mathrm{O}^{+}$), and 2060 (E, altered and $1 \mathrm{~cm}$ below D) of the lower glassy margin (Figure 4). The dry-weight compositions of B, C, and D can be related by least-squares analysis to the composition of fresh glass in the upper margin (from Byerly and Sinton, this volume) as follows: $\mathrm{B}+2.3$ per cent plagioclase, +8.5 per cent olivine, -1.0 per cent clinopyroxene, $C+14.1$ per cent plagioclase, +3.8 per cent olivine, +1.3 per cent clinopyroxene; and $\mathrm{D}+0.5$ per cent plagioclase, +2.2 per cent olivine, +5.8 per cent clinopyroxene. $\mathrm{B}$ appears to have accumulated proportionately more olivine despite its higher position in the core, while $\mathrm{C}$ has preferentially concentrated plagioclase. Both features evidently relate to the posteruptional flow dynamics.

Upper and lower margins show leaching of $\mathrm{Ca}^{+2}$ (extreme) and $\mathrm{Na}^{+}$(very slight), and enrichment of $\mathrm{Si}^{+4}$ and $\mathrm{K}^{+}$, while leaching of $\mathrm{Mg}^{+2}$ occurs at the upper margin only. The lower margin is characterized by a small enrichment of (trivalent?) iron oxide and $\mathrm{Al}_{2} \mathrm{O}_{3}$.

\section{Sub-Unit 592: Sample 74-6, $86 \mathrm{~cm}$ to Sample 74-7,} $20 \mathrm{~cm}$, a Pillow About $80 \mathrm{~cm}$ Thick in Lithologic Unit 13

This unit is moderately phyric, with plagioclase, olivine, and clinopyroxene phenocrysts. Sparse vesicles are filled with smectite and calcite. The upper glassy cooling margin shows extreme alteration to brown-red smectite, with fine fracturing and calcite-smectite veining. Analysis 2120 (A) is of the glass margin and 2130 (B), 1 to $2 \mathrm{~cm}$ below A, is the microcrystalline inner margin. Both samples are phenocryst-free so that the variation (Figure 5) is exclusively an alteration effect. Thus leaching of $\mathrm{Ca}^{+2}$ and $\mathrm{Mg}^{+2}$ (strong) and $\mathrm{Na}^{+}$(less), and enrichment of $\mathrm{K}^{+}$and $\mathrm{Si}^{+4}$ (Figure 4) are a direct result of the rock-water interaction.

Sub-Unit 601: Sample 75-4, $24 \mathrm{~cm}$ to Sample 75-4, $30 \mathrm{~cm}$, a 6-cm-Diameter Single-Rock Piece (pillow?) Probably Belonging to the Same Unit as 5, Bounded at Top and Bottom by Glass

This unit lies 1 meter above the base of lithologic Unit 13 which marks a major stratigraphic break at a depth of about 787 meters (Flower et al., this volume). It is moderately phyric, similar to Sub-units 568 and 569, and the glass margins show considerable alteration to red-brown smectite. The interior of this piece is fresh, however. Analyses
2160 (A) of the upper altered margin, and 2170 (B) of the fresh interior $1 \mathrm{~cm}$ below A (Figure 6), indicate $\mathrm{Ca}^{+2}$ and $\mathrm{Na}^{+}$leaching, and enrichment of $\mathrm{K}^{+}$and $\mathrm{Si}^{+4}$ at the margin. Iron oxide is significantly enriched (as in the lower margin of Sub-unit 569), and so is $\mathrm{MgO}, \mathrm{Al}_{2} \mathrm{O}_{3}$ appears to be slightly depleted.

Least-squares analysis of the data suggests that subtraction of a small amount of plagioclase $(<5 \%)$ from B would produce a composition equivalent to $\mathrm{A}$ in terms of $\mathrm{TiO}_{2}$, $\mathrm{Al}_{2} \mathrm{O}_{3}$, and $\mathrm{FeO}^{* 1}$, with residuals indicating a deficiency of $\mathrm{CaO}, \mathrm{Na} 2 \mathrm{O}$, and $\mathrm{MgO}$ (?) and an excess of $\mathrm{SiO}_{2}$ and $\mathrm{K}_{2} \mathrm{O}$.

Sub-Units 607, 611, and 624 (lithologic Units 14A, B, and C): Three Almost Contiguous, Massive Flow Units Near the Base of Hole $418 \mathrm{~A}$, of 105 Meters Total Vertical Thickness, the Lower Two Units Being Traversed by Dikes

Flow 1: Sample 76-1, $56 \mathrm{~cm}$ to Sample $77-1,50 \mathrm{~cm}$ (Sub-unit 607). This unit is about 6 meters thick and bounded at top and bottom by brecciated glass. It is sparsely phyric to aphyric, with 4 per cent plagioclase, 4 per cent clinopyroxene, and 1 per cent olivine phenocrysts in the samples analyzed: 2180 (A, fresh) and 2190 (B, slightly altered?) (Figure 7). Each sample comes from the flow interior; A from $60 \mathrm{~cm}$ below the upper boundary and B from 3.4 meters below B, some $50 \mathrm{~cm}$ above the lower boundary. The dry-weight compositions are virtually identical, except for slightly higher $\mathrm{K}_{2} \mathrm{O}$, $\mathrm{Na}_{2} \mathrm{O}$, and $\mathrm{TiO}_{2}$ contents and lower $\mathrm{CaO}$ content in $\mathrm{B}$, indicating considerable homogeneity within this flow.

In Figure 7, outlines of fresh flow 2 (horizontal shading) and flow 3 (open) compositions are shown.

Flow 2: Sample $77-2,0 \mathrm{~cm}$ to Sample $79-1,75 \mathrm{~cm}$ (Sub-unit 611). This unit is about 26 meters thick, sparsely phyric to aphyric, with plagioclase more abundant in higher levels. The groundmass is partly altered but as in Flow 1 is mostly fresh, with "juvenile" $\mathrm{H}_{2} \mathrm{O}^{+}$and $\mathrm{K}_{2} \mathrm{O}$ contents. Analyzed samples 2210 (A, phyric $>5 \%$ plagioclase), 2220 (B, sparsely phyric $<5 \%$ plagioclase), 2240 (D, aphyric), 2250 (E, aphyric), and 2260 (F, aphyric) span the middle-to-lower horizons of the flow. Least-squares analysis of the dry-weight compositions (Figure 8) indicates all samples could be cogenetic through differential movement of small amounts of plagioclase ( 2 to $3 \%$ ) and olivine and clinopyroxene $( \pm 1 \%)$, and that incipient alteration did not subject major oxides to mobilization.

In Figure 8, outlines of flow 1 (vertical shading) and flow 3 (open) fresh compositions are shown.

Flow 3: Sample $80-5,110 \mathrm{~cm}$ to Sample 86-1, $26 \mathrm{~cm}$ (Sub-unit 624). This unit is about 73 meters thick and sparsely to moderately phyric (plagioclase 2 to 10 per cent, clinopyroxene 2 to $6 \%$, and olivine 2 to $6 \%$ ). Phenocrysts are again more abundant in upper parts of the flow, while olivine appears dominant at lower and plagioclase at higher levels. Fresh samples 2340 (G), 2350 (H), 2360 (I), 2390 (K), 2400 (L), 2420 (B), 2430 (C), 2440 (D), and 2450 (E) are from representative horizons in the flow unit, while 2410 (A) represents an inner-flow alteration pocket. The fresh analyses show a fairly coherent trend (Figure 9) which

${ }^{1}$ Expressing total iron oxide. 

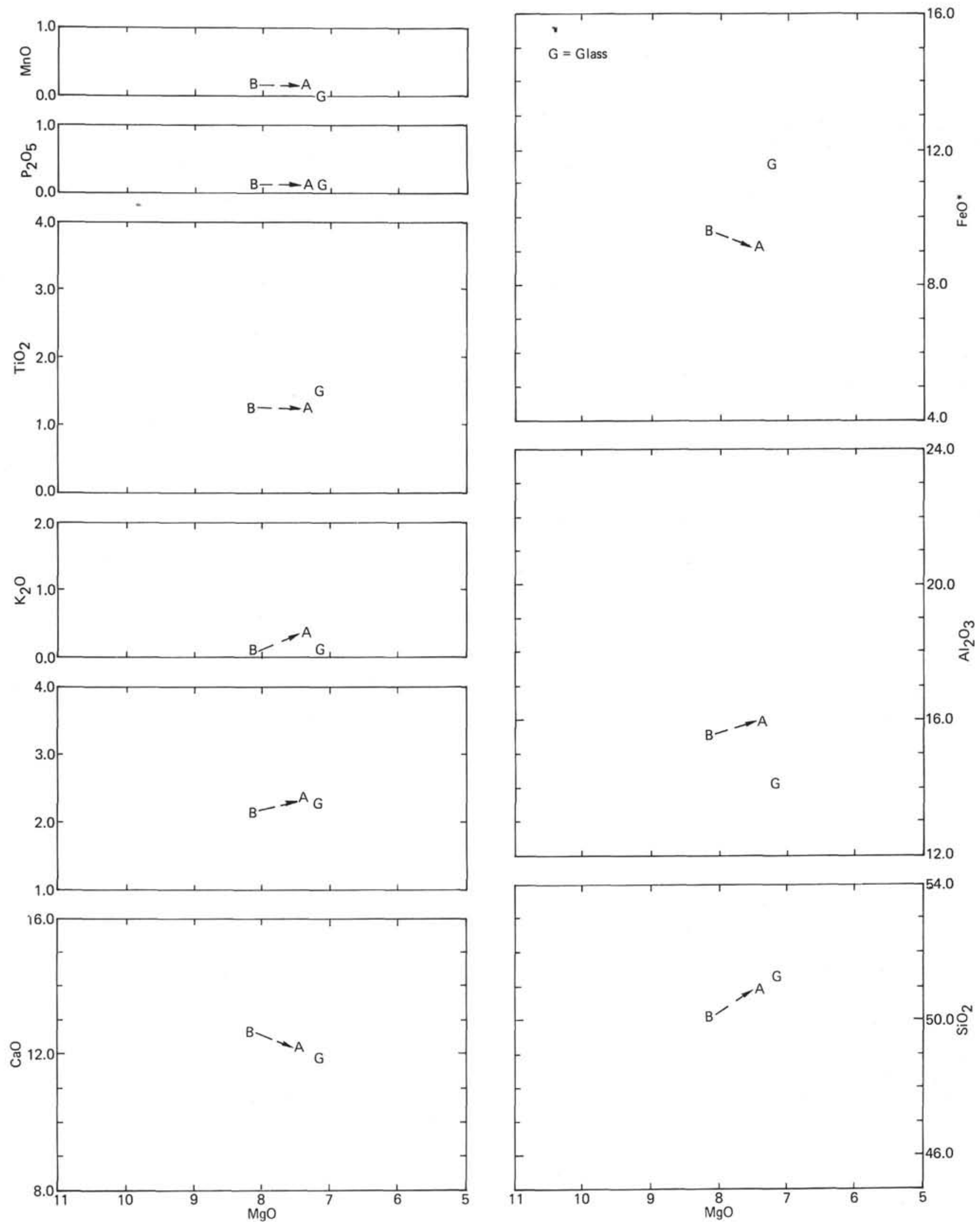

Figure 3. Hole 418A, single cooling unit, lithologic Sub-unit 568, Core 72. Legend as in Figure 1. 

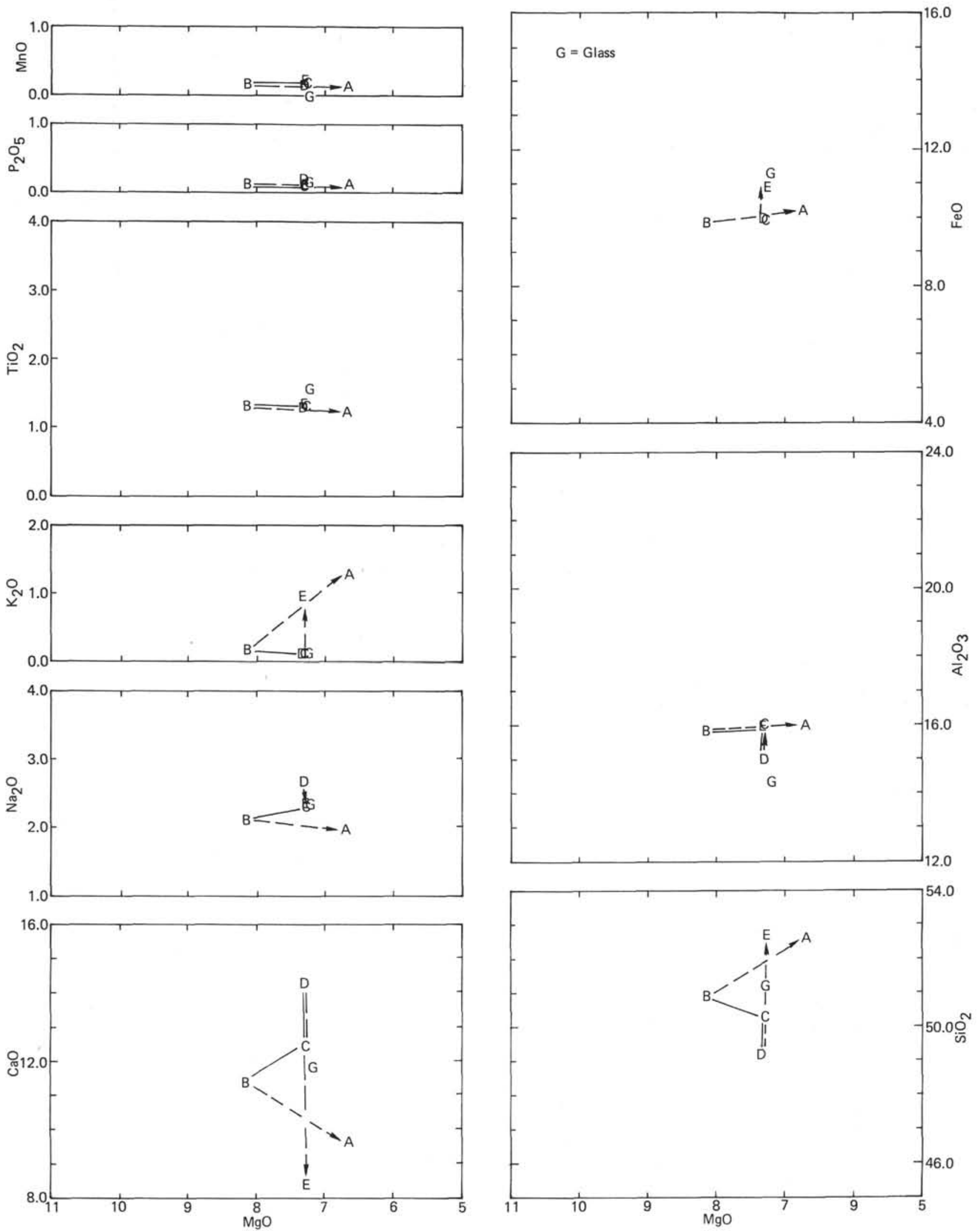

Figure 4. Hole 418A, single cooling unit, lithologic Sub-unit 569, Core 73. Legend as in Figure 1. 

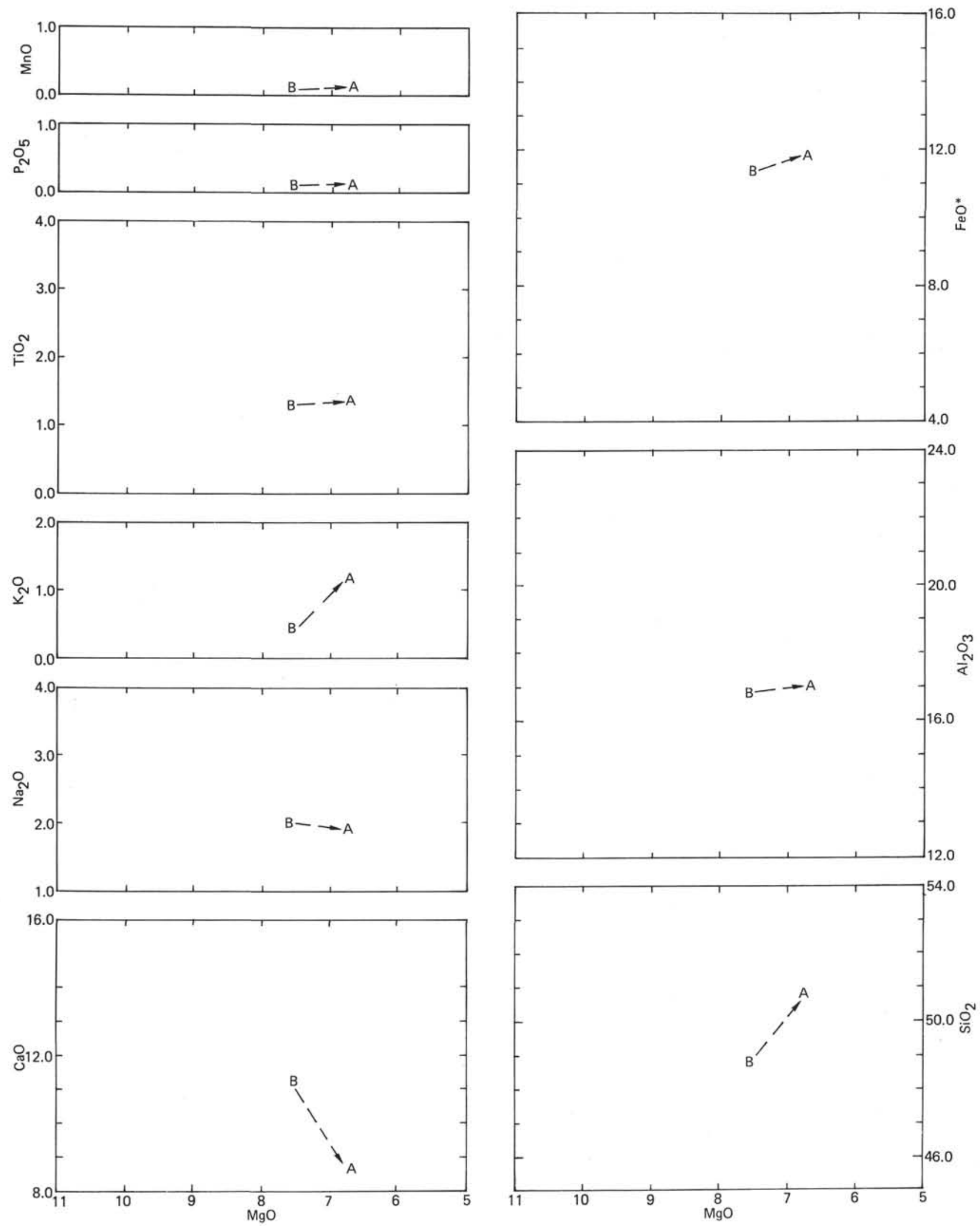

Figure 5. Hole 418A, single cooling unit, lithologic Sub-unit 592, Core 74. Legend as in Figure 1. 

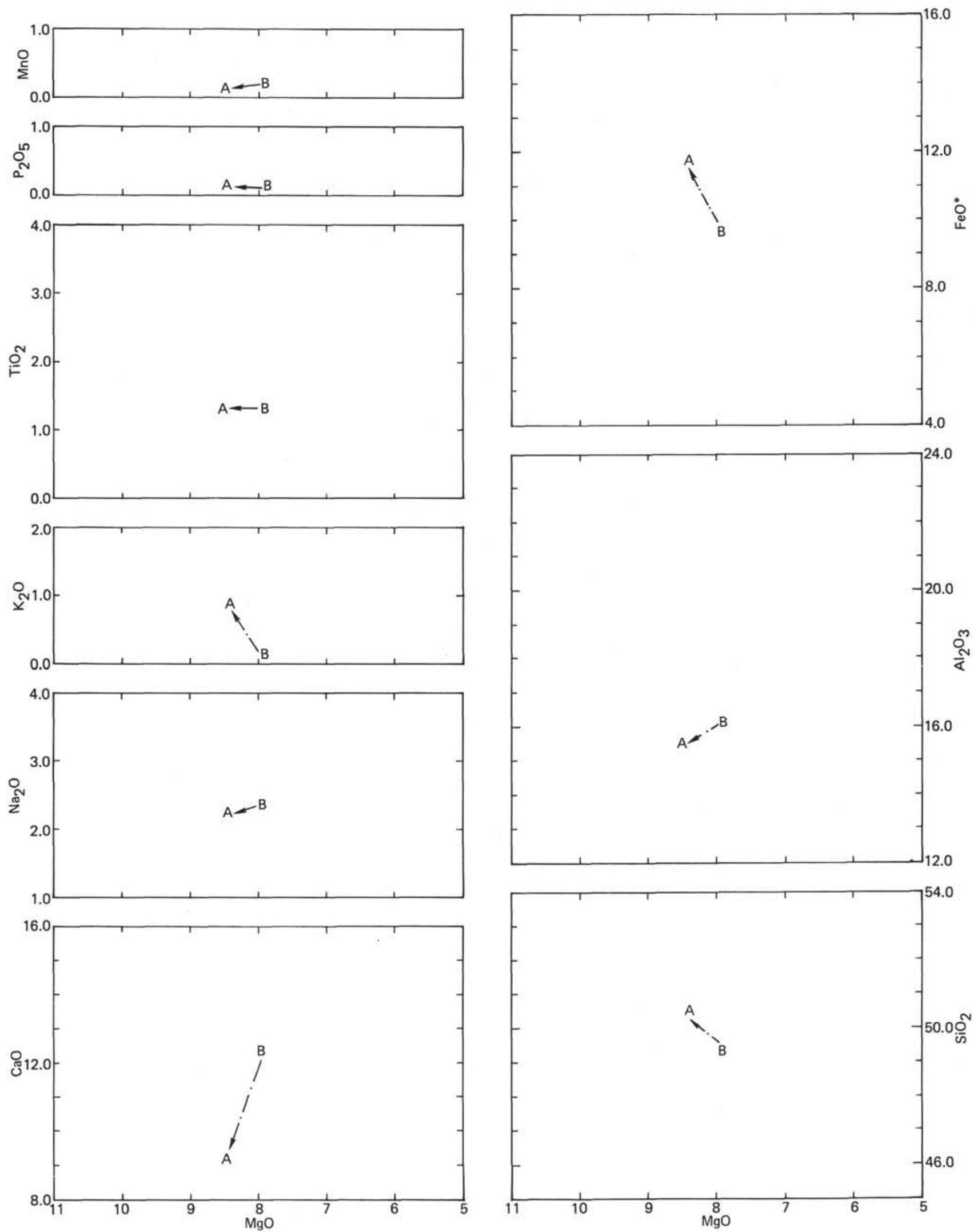

Figure 6. Hole 418A, single cooling unit, lithologic Sub-unit 601, Core 75. Legend as in Figure 1. 

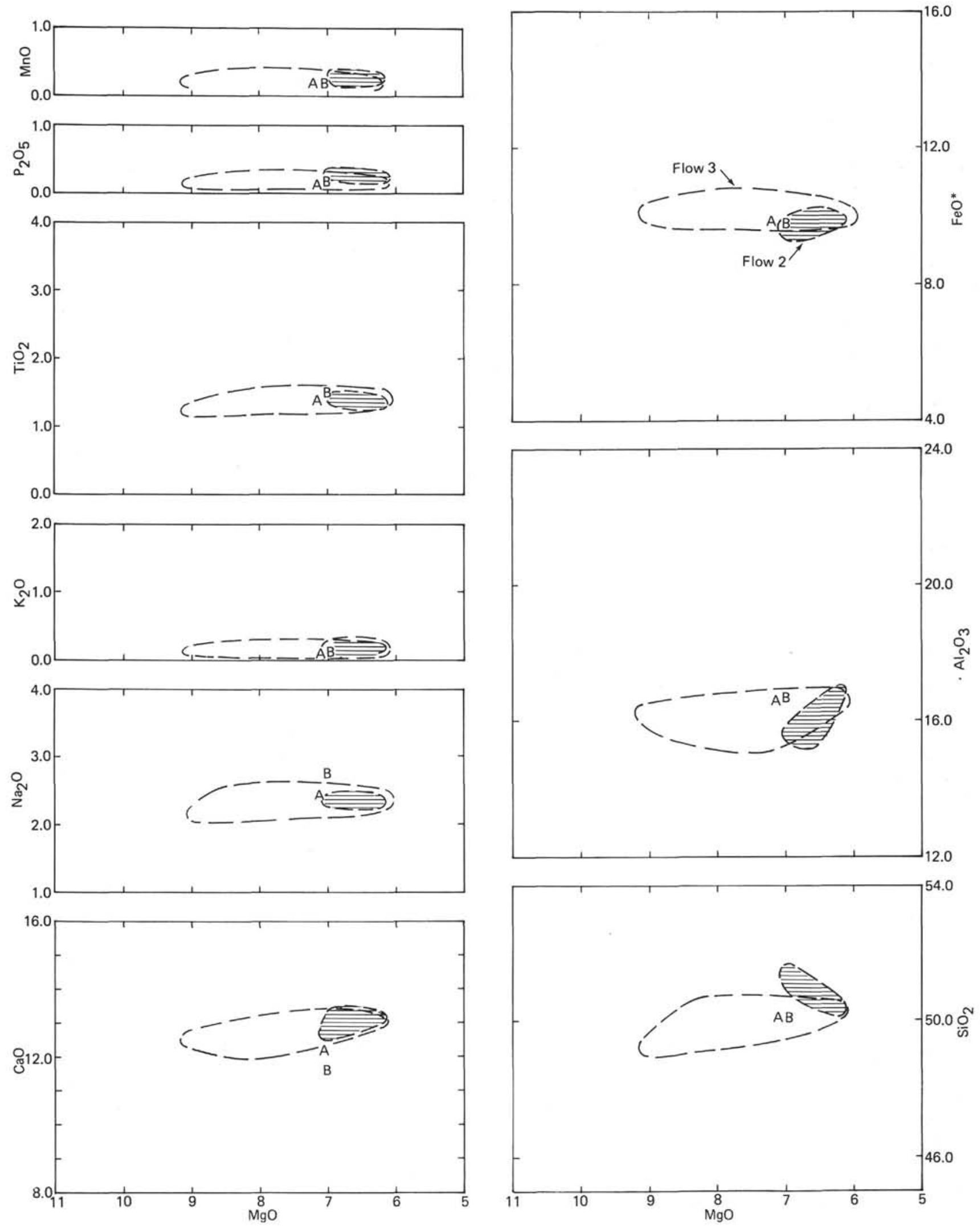

Figure 7. Hole 418A, single cooling unit, lithologic Sub-unit 607, Core 76. Legend as in Figure 1. 

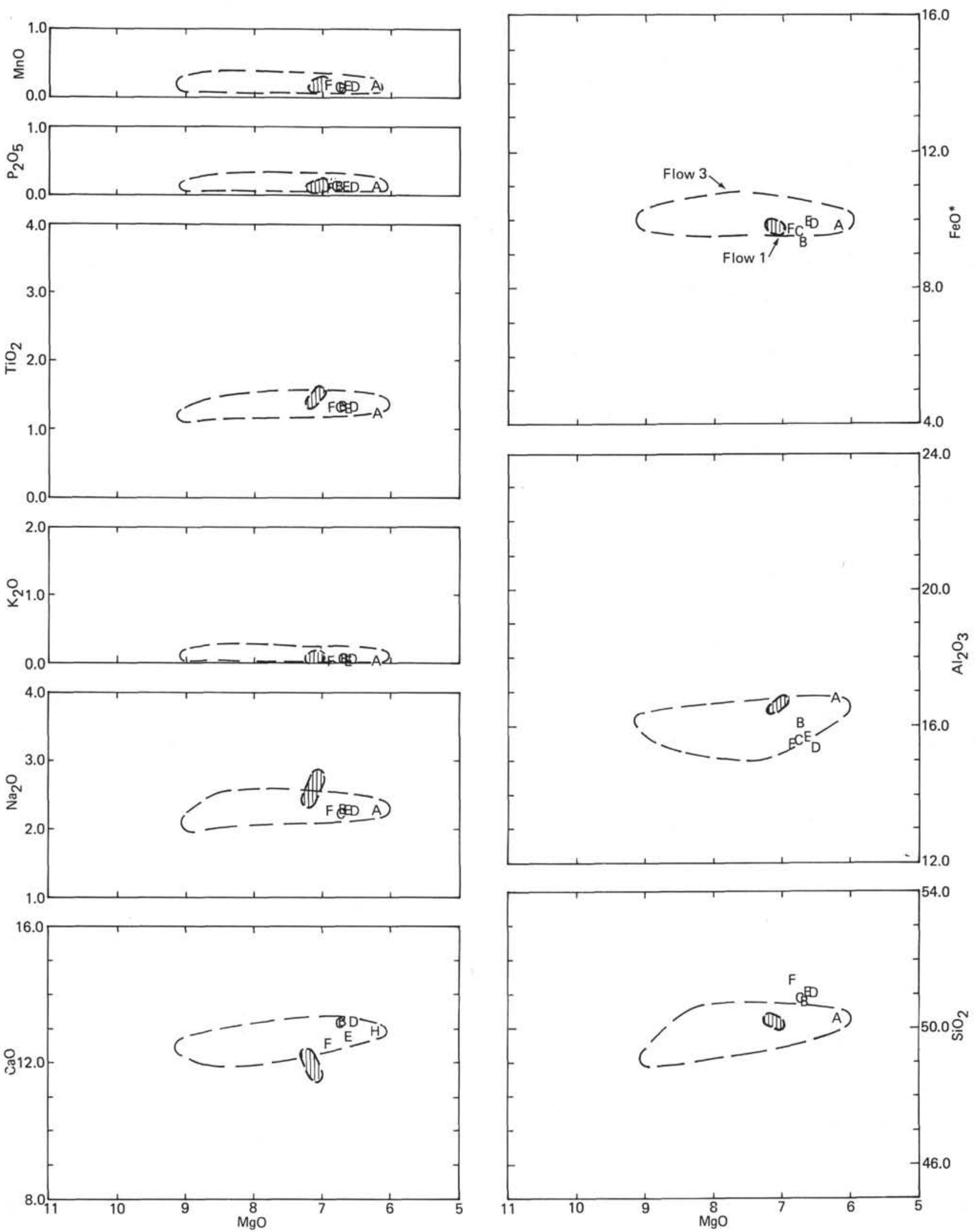

Figure 8. Hole 418A, single cooling unit lithologic Sub-unit 611, Cores 77 to 79. Legend as in Figure 1. 

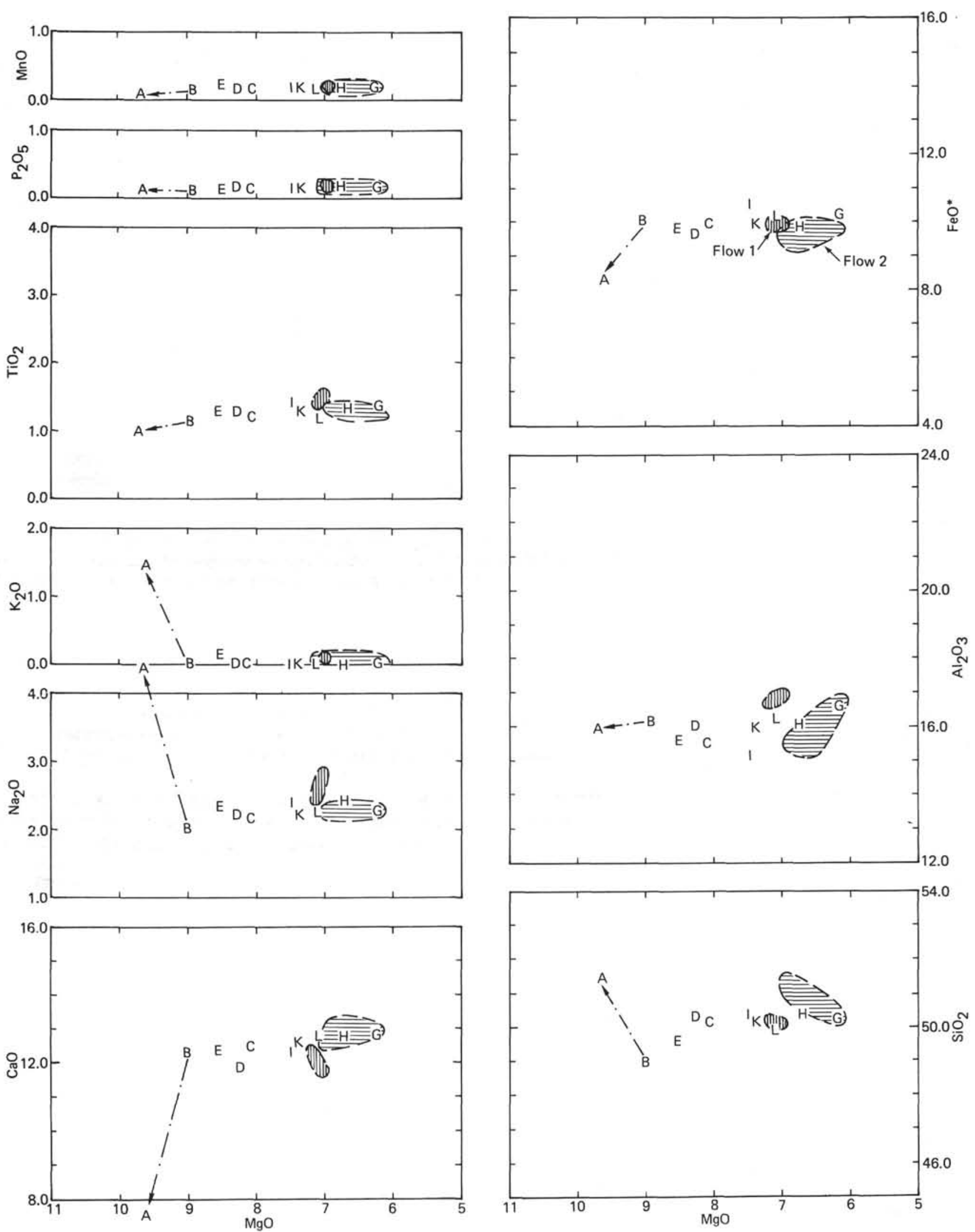

Figure 9. Hole 418A, single cooling unit, lithologic Sub-unit 624, Cores 80 to 86. Legend as in Figure 1. 
accommodates simple redistribution of plagioclase, olivine, and clinopyroxene in variable proportions. However, the approximately 20 per cent addition or subtraction of plagioclase (and somewhat lesser amounts of mafic phases) required by least-squares solutions bears little relation to the observed phenocryst modes. The fractionation observed may thus derive from syn- or pre-eruptive processes, so that this unit may comprise a series of distinct extrusions in rapid succession.

Lithologic Units 14A, B, and C are almost certainly cogenetic in terms of shallow-level processes according to our modeling (see Figure 9, where flow 3 compositions are compared with flows 1 and 2). Although glass cooling boundaries were not observed at the flow margins, and it was not possible to monitor liquid-fraction compositions, the variation of "aphyric"' compositions strongly support this relationship. The variation cannot however be caused by simple removal of a three-phase assemblage from a parent liquid composition, but necessarily involves differential accumulation and/or removal of phases before the eruption.

\section{Sub-Units 542, 543, and 544: Sample 70-4, $0 \mathrm{~cm}$ to Sample 70-5, $106 \mathrm{~cm}$, a 2- to 3-Meter-Thick Complex Cooling Unit in Lithologic Unit 13}

Shipboard lithologic and structural studies suggest these subunits represent a section through a "flow-tube," comprising an inner "tube" (Sub-unit 543) of fine-grained, nearly aphyric basalt, enclosed above (Sub-unit 542) and below (Sub-unit 544) by an envelope of more coarsely phyric basalt, with apparent chilling along the edges of the "tube"' (see Site Chapter, Hole 418A, Lithology; this volume).

Sample analyses 1930 (A, upper envelope, fresh); 1940 (B, inner "'tube," fresh); 1950 (C, inner “tube," altered); and 1960 (D, lower envelope; fresh) show variation consistent with this postulate (Figure 10). A and D show a simple relationship, whereby $\mathrm{D}$ may be derived from $\mathrm{A}$ by addition of 5.3 per cent plagioclase, and removal of 1.3 per cent olivine and 0.3 per cent clinopyroxene, without significant residuals for any oxide. "Inner tube" compositions are distinct from the "envelope" and require a proportionately large clinopyroxene component removed from (and possibly iron-titanium oxide added to) the envelope compositions if the two bear a shallow-level cogenetic relationship. B shows the effects of $\mathrm{Ca}^{+2}$ and $\mathrm{Mg}^{+2}$ leaching and slight enrichment of $\mathrm{Si}^{+4}$ and iron oxide in relation to $\mathrm{C}$, but was almost certainly an original magma composition identical to $\mathrm{C}$.

\section{TRACE ELEMENT VARIATION}

Selected shipboard samples were analyzed for $\mathrm{Rb}, \mathrm{Sr}, \mathrm{Y}$, $\mathrm{Zr}$, and $\mathrm{Nb}$ shortly after completion of Leg 53 . These data (except for $\mathrm{Rb}$, which was mostly below the level of detection) are given in Table 3. In Figure 11, Sr, $\mathrm{Y}$, and $\mathrm{Zr}$ are plotted versus $\mathrm{TiO}_{2}$ for three low-temperature alteration fronts confirmed from major element variation, and for the flow interior (Sub-unit 624) where alteration is superimposed on phenocryst redistribution effects. "Fresh' intraunit variation is shown for Sub-unit 611 and 624 massive flow units. This highlights the susceptibility of $\mathrm{Sr}$ to alteration which, in contrast to $\mathrm{Ca}^{+2}$, is enriched in the basalt
(Figure 12). Discrepancies of $\mathrm{Zr}$ and $\mathrm{Y}$ in relation to $\mathrm{TiO}_{2}$, in fresh intra-flow variation trends, are very small, except for the flow interior of Sub-unit 624, where the altered sample shows the effect of accumulated mafic phase(s) (Figure 9) and simple dilution of $\mathrm{TiO}_{2}, \mathrm{Zr}$, and $\mathrm{Y}$ (Figure 11).

\section{SUMMARY}

We have attempted to differentiate between the effects of phenocryst redistribution and low-temperature alteration upon chemical variation within single cooling units. Low vesicle and amygdule contents and the predominance of calcite in veins permit simple corrections to be made to rock analyses for identification of magma compositions. Carbonate contamination appears to be separate (at least in its net effect) from contamination that causes other clearly recognized element-transfer patterns. These have been identified at pillow margins and in a massive flow interior (Table 4; Figure 13). In three instances they show leaching of $\mathrm{Ca}^{+2}$, $\mathrm{Mg}^{+2}$, and, with one exception, $\mathrm{Na}^{+}$, and enrichment of $\mathrm{K}_{+}$ and $\mathrm{Si}^{+4}$. $\mathrm{Na}^{+}$enrichment occurs in the massive flow interior of Sub-unit 624 . There is a very slight tendency for $\mathrm{Al}^{+3}$ to increase with alteration (Table 4), while $\mathrm{Fe}^{+3(?)}$ is significantly enriched in Sub-unit 569 (lower margin) and depleted in the flow interior of Sub-unit 624. Iron hydroxides occur in oxidized zones, but these are notably less common at Hole 418A than in newer crust (Robinson et al., this volume). Other data sets (e.g., Flower et al., this volume) show good correlation of $\mathrm{Fe}_{2} \mathrm{O}_{3} / \mathrm{FeO}$ with $\mathrm{K}_{2} \mathrm{O}$ but not with $\mathrm{H}_{2} \mathrm{O}+$. For detailed treatment of the secondary-phase chemistry developed in association with these bulk-rock trends, the reader is referred to reports by Robinson et al.; Pritchard et al.; Juteau et al.; and Rusinov et al. (all this volume).

The major-oxide alteration patterns are similar to those observed previously in ocean floor basalts (e.g., Hart, 1973; Thompson, 1973; and Baragar et al., 1977), with the important exception of $\mathrm{Si}^{+4}$ which had been reported as a leached element. This may be a result of comparatively unadvanced alteration, as $\mathrm{Si}^{+4}$ enrichment is not evident in advanced low-temperature alteration at Hole 417A (Donnelly et al., this volume), but may also reflect a regional/temporal difference of Cretaceous crust from the MAR. Amorphous silica, as an accompaniment to calcite and smectite in veins and groundmass, is more abundant at Hole $418 \mathrm{~A}$ than at Hole 332 (Robinson et al., this volume).

No single chemical parameter can be used to define the degree of alteration. In particular, water, the chief reagent, is not present as a structural component in proportion to the overall chemical changes in basalt resulting from its percolation through the pile. The $\mathrm{Eh}$ and $\mathrm{pH}$ of the fluid and the variable physical controls on $\mathrm{Na}^{+}, \mathrm{K}^{+}$, and $\mathrm{Ca}^{+2}$ exchange between rock and water determine the smectite compositions developed at alteration fronts and during pervasive replacement of groundmass material. The fluid composition is further influenced by the rate and type of sediment deposition, and, because of variable leaching susceptibilities, the porosity and permeability of the basalt pile. Movement of $\mathrm{Na}^{+}$, for example, which appears to be both lost and gained during alteration, may be a function of permeability and the relative fixation rates of, for example, montmorillonite, 

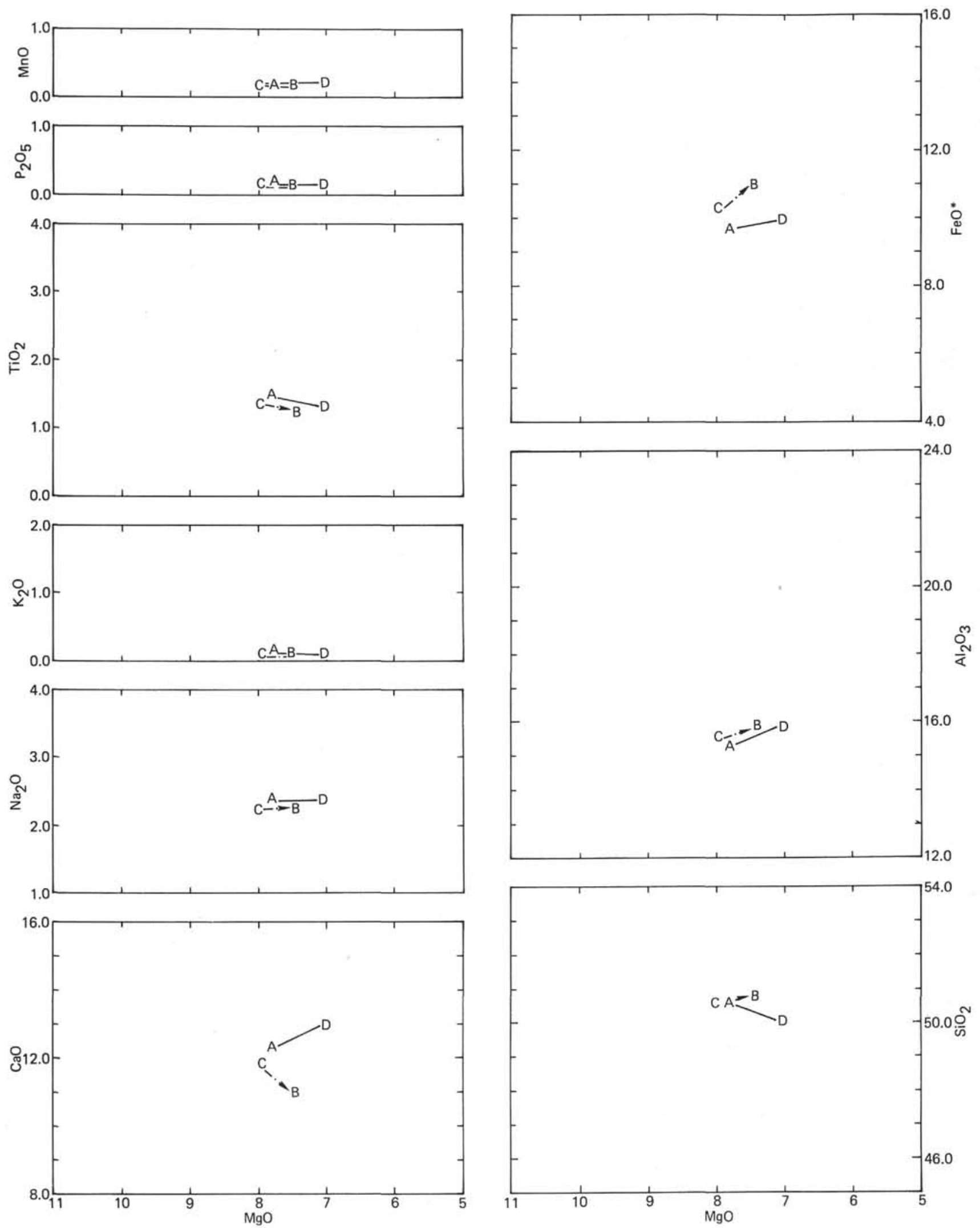

Figure 10. Hole 418A, single cooling unit, lithologic Sub-unit 452/3/4, Core 70. Legend as in Figure 1. 
TABLE 3

Trace Element Analyses (ppm) Used in Single Cooling-Unit Studies ${ }^{\mathrm{a}}$

\begin{tabular}{lcrccc}
\hline $\begin{array}{l}\text { Computer } \\
\text { File No. }\end{array}$ & Sub-Unit & $\mathrm{Sr}$ & $\mathrm{Y}$ & $\mathrm{Zr}$ & $\mathrm{Nb}$ \\
\hline $1550 \mathrm{~A}^{\mathrm{b}}$ & 398 & 106.3 & 29.0 & 71.3 & 2.8 \\
1560 & - & 97.0 & 25.1 & 77.6 & 2.4 \\
1570 & - & 106.0 & 25.5 & 76.5 & 1.8 \\
1930 & 542 & 111.2 & 24.4 & 69.7 & 2.3 \\
$1940 \mathrm{~A}$ & 543 & 100.3 & 27.3 & 82.6 & 4.2 \\
1950 & - & 103.8 & 27.0 & 78.6 & 6.0 \\
1960 & 544 & 117.7 & 26.3 & 75.3 & 3.7 \\
$2000 \mathrm{~A}$ & 568 & 141.4 & 23.3 & 73.2 & - \\
2010 & - & 109.0 & 24.9 & 76.7 & 5.6 \\
2020 & 569 & 126.6 & 22.7 & 70.5 & 2.6 \\
2030 & - & 106.0 & 23.7 & 69.3 & 3.8 \\
2040 & - & 103.0 & 25.4 & 71.8 & 1.2 \\
2050 & - & 110.5 & 22.8 & 71.4 & 1.7 \\
$2060 \mathrm{~A}$ & - & 132.4 & 21.7 & 71.5 & 4.1 \\
$2120 \mathrm{~A}$ & 592 & 123.6 & 24.0 & 72.1 & 2.3 \\
2130 & - & 96.8 & 25.0 & 74.5 & 3.7 \\
$2160 \mathrm{~A}$ & 601 & 113.4 & 25.0 & 74.5 & 3.7 \\
2170 & - & 110.4 & 26.6 & 75.2 & 3.6 \\
2180 & 607 & 114.1 & 25.4 & 75.3 & 3.7 \\
2210 & 611 & 112.4 & 23.0 & 68.3 & 2.3 \\
2230 & - & 120.0 & 23.6 & 70.2 & 1.9 \\
2250 & - & 106.1 & 24.2 & 74.4 & 2.8 \\
2340 & 624 & 107.3 & 26.3 & 76.0 & 2.2 \\
2360 & - & 99.8 & 29.1 & 78.9 & 3.0 \\
2390 & - & 98.2 & 26.1 & 72.9 & 1.4 \\
$2410 \mathrm{~A}$ & - & 174.0 & 17.0 & 51.5 & 0.1 \\
2420 & - & 99.3 & 23.3 & 65.7 & 1.5 \\
2440 & - & 103.3 & 23.9 & 68.9 & 3.6 \\
\hline & & & & & \\
\hline & & & & & \\
\hline
\end{tabular}

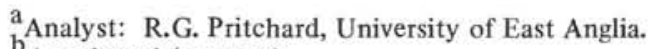
${ }_{\mathrm{A}}=$ altered (see text). celadonite, and saponite. During protracted water circulation (evidenced at Hole 417A), early alteration assemblages will have reacted with the evolving fluid composition, and, as physical conditions changed, before the final "sealing" of the crust. The alteration at Hole 418A clearly represents an abbreviated early stage, although Hole 417A patterns, except for $\mathrm{Si}^{+4}$, are largely an extension of the incipient patterns observed at Hole 418A.

\section{ACKNOWLEDGMENTS}

We thank DSDP for funding the computer analyses, D.F.G. and N.E.R.C. for funding post-cruise analyses, and Dr. W. G. Melson for critically reading the manuscript.

\section{REFERENCES}

Baragar, W. R. A., Plant, A. G., Pringle, G. J., and Schaw, M., 1977. The petrology of alteration in three distinct flow units of Sites 332 and 335. In Aumento, F., Melson, W. G., et al., Initial Reports of the Deep Sea Drilling Project, v. 37: Washington (U.S. Government Printing Office), p. 811-820.

Hart, R., 1973. Geochemical and geophysical implications of the reaction between seawater and the ocean crust, Nature, v. 234, p. 76-78.

Pearce, J. A. and Cann, J. R., 1971. Ophiolite origin investigated by discriminant analysis using $\mathrm{Ti}, \mathrm{Zr}$ and $\mathrm{Y}$, Earth Planet. Sci. Lett., v. 12, p. 339-350.

Pearce, T. H., Gorman, B. E., and Birkett, T. C., 1977. The relationship between major element chemistry and tectonic environment of basic and intermediate volcanic rocks, Earth Planet. Sci. Lett., v. 36, p. 121-132.

Thompson, G., 1973. A geochemical study of the low temperature interaction of seawater and oceanic igneous rocks, EOS, Trans. Am. Geophys. Union, v. 54, p. 1015-1019. 


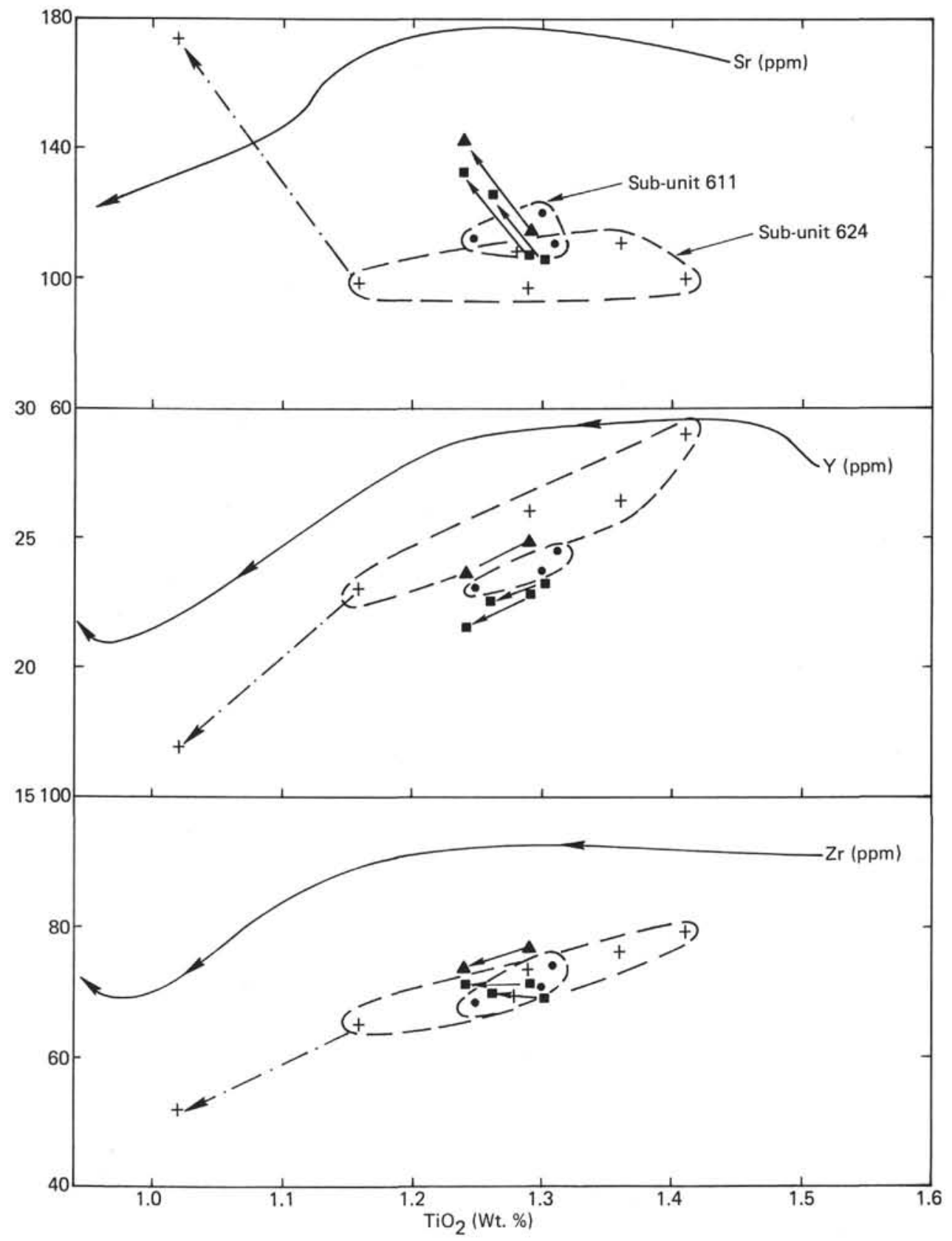

Figure 11. Plots of $\mathrm{Sr}, \mathrm{Y}$, and $\mathrm{Zr}$ (ppm) versus $\mathrm{TiO}_{2}$ (wt. \%), showing: (a) variation due to alteration (continuous arrows); (b) variation due to alteration and phenocryst movement in Sub-unit 624 (dot-dash arrow); and (c) fresh-rock variation of Sub-units 611 and 624. Symbols: Sub-unit $624+; 611 \bullet ; 569 \mathbf{m} ; 568$. 


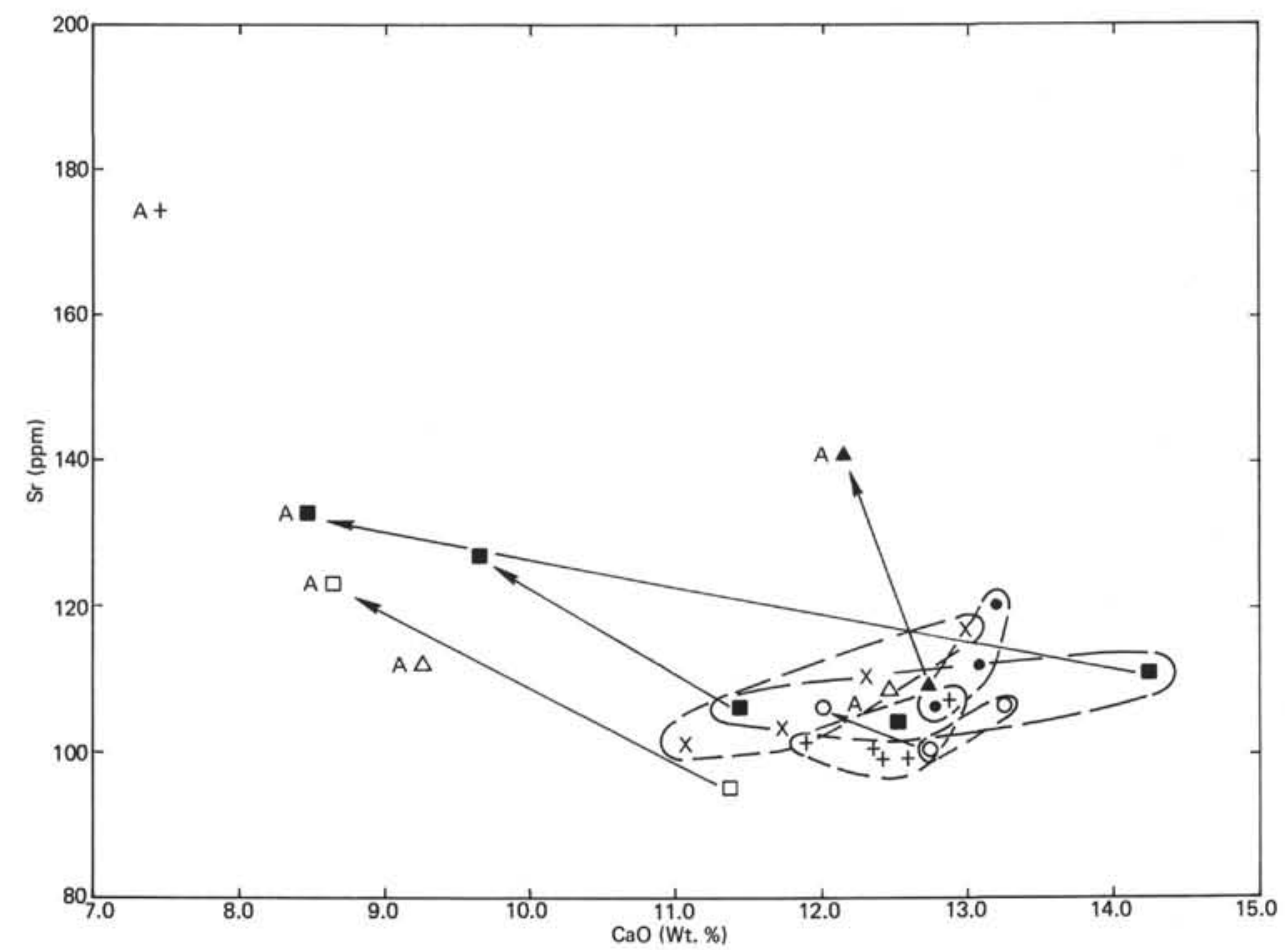

Figure 12. Plots of $\mathrm{Sr}(\mathrm{ppm})$ versus $\mathrm{CaO}$ (wt. \%); "fresh" single-unit variation is outlined, in contrast to low-temperature alteration trends (arrows); $A=$ altered samples. Symbols: Sub-unit 398 o; $542-544$ X; 568 «; 569 •; 592 ; 601 ४; $611 \bullet ; 624$ +.

TABLE 4

Mass Change of Oxides in $\mathrm{g} / \mathrm{cm}^{3}$ Between Fresh and Altered Portions of Single Cooling Units, Hole 418A

\begin{tabular}{lccccc}
\hline Sub-Unit & $\begin{array}{c}568 \\
\text { (upper } \\
\text { margin) }\end{array}$ & $\begin{array}{c}569 \\
\text { (upper } \\
\text { margin) }\end{array}$ & $\begin{array}{c}569 \\
\text { (lower } \\
\text { margin) }\end{array}$ & $\begin{array}{c}592 \\
\text { (upper } \\
\text { margin) }\end{array}$ & $\begin{array}{c}624 \\
\text { (flow } \\
\text { interior) }\end{array}$ \\
\hline $\mathrm{SiO}_{2}$ & Figure 11 & (b) & (b) & (c) & (d) \\
$\mathrm{Al}_{2} \mathrm{O}_{3}$ & +1.26 & +0.81 & +2.52 & +0.63 & -0.48 \\
$\mathrm{FeO}^{*}$ & -1.35 & +0.98 & +2.88 & +1.53 & -4.44 \\
$\mathrm{MgO}_{\mathrm{CaO}}$ & -2.07 & -4.26 & -0.09 & -2.49 & +2.01 \\
$\mathrm{Na}_{2} \mathrm{O}$ & -1.56 & -5.40 & -17.4 & -8.07 & -14.82 \\
$\mathrm{~K}_{2} \mathrm{O}$ & +0.48 & -4.50 & -0.87 & -0.24 & +7.20 \\
$\mathrm{H}_{2} \mathrm{O}^{+}$ & +0.84 & +3.39 & +2.43 & +2.34 & +4.29 \\
$\mathrm{TiO}_{2}$ & +1.11 & +3.63 & -5.70 & -12.09 & +11.76 \\
& -0.15 & -0.12 & +0.15 & +0.09 & -0.42 \\
Sample File & $2010-$ & $2030-$ & $2060-$ & $2130-$ & $2420-$ \\
No. & 2000 & 2020 & 2050 & 2120 & 2410 \\
& & & & & \\
Symbols Used & $\mathrm{B}-\mathrm{A}$ & $\mathrm{B}-\mathrm{A}$ & $\mathrm{D}-\mathrm{E}$ & $\mathrm{B}-\mathrm{A}$ & $\mathrm{B}-\mathrm{A}$ \\
Figure No. & 3 & 4 & 4 & 5 & 8 \\
\hline
\end{tabular}




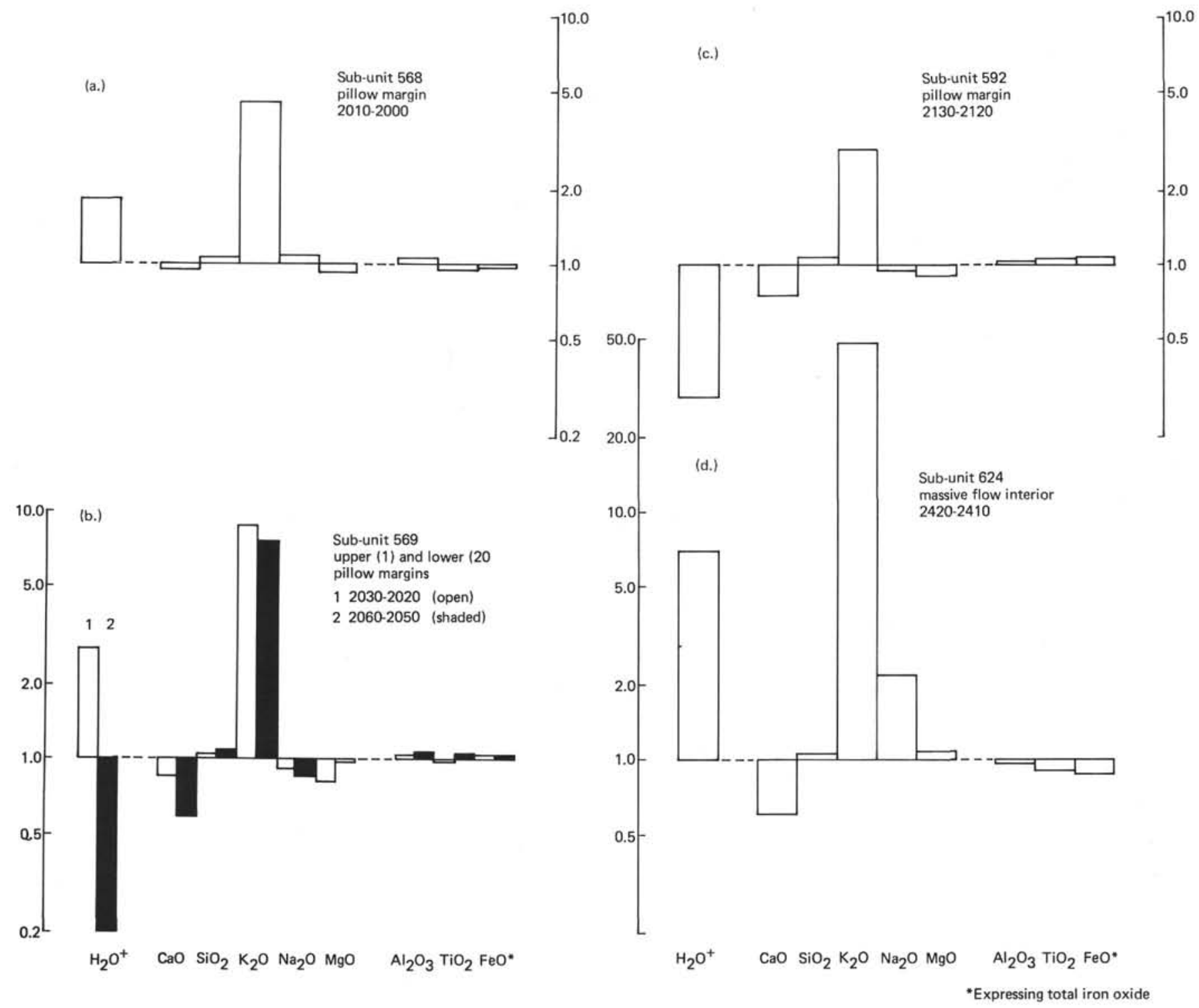

Figure 13. Major-oxide changes due to low-temperature alteration; ratios of altered:fresh-rock oxide abundances. 